\title{
Where can flood refugees go? Re-distribution of Corncrakes (Crex crex) due to floods and its consequences on grassland conservation in North-Eastern Hungary
}

\author{
Sándor András Boldogh* ${ }^{* 1,2}$, Tamás VisnyovszKY ${ }^{1,2}$, Zsolt Szegedi ${ }^{1}$, \\ Béla HabArics ${ }^{3}$, Róbert Horváth ${ }^{4}$, Cecília KRAJNYÁK ${ }^{1}$ \\ \& Szabolcs LENGYEL ${ }^{5}$
}

Received: October 6, 2016-Accepted: November 23, 2016

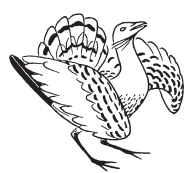

Sándor András Boldogh, Tamás Visnyovszky, Zsolt Szegedi, Béla Habarics, Róbert Horváth, Cecília Krajnyák \& Szabolcs Lengyel 2016. Where can flood refugees go? Re-distribution of Corncrakes (Crex crex) due to floods and its consequences on grassland conservation in North-Eastern Hungary. - Ornis Hungarica 24(2): 18-31.

\begin{abstract}
The Corncrake is a threatened umbrella species for wet meadows, which mostly depends on managed grasslands. Therefore, effective conservation requires bird-friendly land management schemes and subsidies. Although the most important populations in Hungary usually breed in protected areas, some of these are regularly flooded, which forces Corncrakes to find breeding sites elsewhere. Such movements from protected/subsidised areas to suboptimal sites have risks for Corncrake populations and their conservation. Here, we describe a largescale dynamic system of interlinked populations based on data from 4194 Corncrake territories found at four different sites (Aggtelek, Bodrogzug, Szatmár-Bereg and Zemplén regions) across eight years between 1997 and 2006 in NE Hungary (c. $1500 \mathrm{~km}^{2}$ ). The results showed that the total population fluctuated between 407 and 631 pairs and that the populations were more-or-less stable in the first four years (1997-2000). However, extended floods caused the disappearance of the species from the Bodrogzug region in 2005-2006, while in the other sites, the number of territories increased five-fold (Zemplén), three-fold (Aggtelek) and two-fold (Szatmár-Bereg). The correlation between the number of territories and maximum water level of river Tisza in April-May was negative in the Bodrogzug site and positive in the three other sites, indicating that interlinkages of the populations were associated with water levels. Our data thus support the hypothesis that many of the birds driven out by inundation of floodplain meadows moved to other sites in NE Hungary in flood years. These results suggest that even large, centrally located populations of Corncrake can be greatly exposed to risks of flooding and that it is highly important to maintain suitable alternative breeding sites for the species. The High Natural Value Areas programme may allow administrative and funding support to provide or extend protection and/or subsidies to maintain this largescale dynamic system. To this end, the area managed in bird-friendly ways and subsidised under agri-environmental schemes was extended by 35,000 hectares in NE Hungary in 2009.
\end{abstract}

Keywords: Corncrake, High Nature Value Areas, grassland protection, agri-environment schemes, landscape scale

Összefoglalás A haris a nedves gyepek kitüntetett ernyőfaja. A faj napjainkban leginkább mezőgazdasági hasznosítású gyepterületekhez kötődik, ezért hatékony védelme madárbarát gazdálkodási gyakorlatot és agrár-támogatásokat igényel. Habár a legjelentősebb hazai állományok védett területeken költenek, ezen területeket rendszeresen érik áradások, melyek más költőhelyek keresésére kényszeríthetik a harisokat. A védett/támogatott területekröl szuboptimális költőhelyekre történő mozgások kockázatosak lehetnek a haris-állományokra, és kihívást jelentenek a védelem számára. Dolgozatunkban négy állomány nagy térbeli léptékủ, dinamikus kapcsoltsági rendszerét ismertetjük négy északkelet-magyarországi helyszínen (Aggtelek, Bodrogzug, Szatmár-Bereg, Zemplén) nyolc éven át (1997-2006) gyüjtött 4194 haris-territórium adata alapján. Az összesített állomány 407 és 631 pár között változott, és az első négy vizsgálati évben (1997-2000) viszonylag stabil volt az egyes helyszíneken. A második négyéves periódus végére (2005-2006) azonban a bodrogzugi állomány szinte eltünt a hosszú árvizek hatására, 


\section{Krajnyák \& Sz. Lengyel}

míg a többi helyszínen a territóriumok száma megduplázódott (Szatmár-Bereg), illetve a háromszorosára (Aggtelek) vagy ötszörösére nőtt (Zemplén). A territóriumok száma és a Tisza április-májusi maximum vízállása közötti korreláció negatív volt a Bodrogzug esetén, és pozitív a többi helyszín esetén, mely arra utalt, hogy az állományok közötti kapcsolatok összefüggésben voltak a vízállással. Adataink ezért alátámasztják azt az elképzelést, miszerint a nyílt ártéri rétek elárasztása révén költőhelyükről elüldözött madarak más északkelet-magyarországi helyszínekre kényszerülnek az árvizes években. Ezek az eredmények azt mutatják, hogy még nagy, középponti helyzetben levő haris-állományok (pl. Bodrogzug) számára is kockázatokat jelenthet az árvíz, és ezért megfelelő alternatív költőhelyeket kell fenntartani a fajnak. A Magas Természeti Értékủ Területek program adminisztratív és anyagi segítséget nyújthat a védelem és a támogatások biztosítására és kiterjesztésére e nagy térbeli léptéken müködő dinamikus rendszer fenntartása érdekében. E célból történt meg a madárbarát múvelési gyakorlat és az agrár-környezetvédelmi támogatási rendszerek áttervezése és bővítése újabb, összesen 35000 hektár területre Északkelet-Magyarországon 2009-ben.

Kulcsszavak: haris, Magas Természeti Értékü Területek, füves élőhelyek védelme, agrár-környezetgazdálkodási rendszer, tájlépték

${ }^{1}$ Aggtelek National Park Directorate, 3758 Jósvafö, Tengerszem oldal 1., Hungary, e-mail address: sandorboldogh@yahoo.com

${ }^{2}$ BirdLife Hungary Gömör-Torna Working Group, 3758 Jósvafö, Kültelek 1., Hungary

${ }^{3}$ Hortobágy National Park Directorate, Nyirség-Szatmár-Bereg Természetvédelmi Tájegység, 4024 Debrecen, Sumen utca 6., Hungary

${ }^{4}$ Szabolcs-Szatmár-Beregi Nature Conservation Fund, 4921 Kisar, Árpád utca 26., Hungary

${ }^{5}$ Hungarian Academy of Sciences, Centre for Ecological Research, Danube Research Institute, Department of Tisza Research, 4026 Debrecen, Bem tér 18/c., Hungary

*corresponding author

\section{Introduction}

Grasslands cover approximately $40 \%$ of the terrestrial area of the world, and about $20 \%$ of Europe (Suttie et al. 2005). Grasslands are important habitats for wildlife, but at the same time, they are also significant for agricultural production (Hopkins \& Holz 2006). The area of grasslands in Europe has decreased during the past decades, whereas the management of the remaining areas has intensified (European Environment Agency 2007, Pe'er et al. 2014). The decline in biodiversity in grasslands due to agricultural intensification is well-known all over Europe (Chamberlain et al. 2000, Donald et al. 2001, Benton et al. 2002, Donald et al. 2006, Henle et al. 2008, Kleijn et al. 2009, Pe'er et al. 2014).

The Corncrake is known to depend on managed grasslands (Green et al. 1997, Schäffer $\&$ Koffijberg 2004), but the increased intensity of grassland management has a negative impact on this species (Green \& Rayment 1996, Berg \& Gustavson 2007). Consequently, the population size of this formerly abundant bird has decreased in major parts of its Eurasian breeding range (Green et al. 1997, Keišs 2005, Keišs et al. 2007). The northern and western European populations in particular are scattered and are now endangered (Green 1995, Crockford et al. 1996, Schäffer \& Koffijberg 2004). In contrast, populations in Central and Eastern Europe (CEE) were reported to increase (Koffijberg et al. 2016), which may be related to the disappearance of the collective farming systems and general temporary extensification of agriculture due to the collapse of the socialist economy (e.g. Elts 1997, Keišs 1997, Schäffer \& Green 2001, Keišs 2005, Koffijberg \& Schäffer, 2006, Koffijberg et al. 2016). In addition, comprehensive conservation schemes have been established in several 
countries (Stowe \& Green 1997, O’Brien et al. 2006, Schoppers \& Koffijberg 2006, Beaumont \& England 2016). Otherwise, abandonment of management of grasslands, which has been occurring in many CEE areas, enhances vegetation succession and eventually drives out Corncrakes as the vegetation becomes too dense (Schäffer \& Koffijberg 2004, Koffijberg et al. 2016).

Today, agricultural subsidies increasingly result in the expansion of arable lands and in a simultaneous reduction and even more intensive use of grasslands, especially in the new CEE member states of the EU (e.g. Pe'er et al. 2014), which is unfavourable for Corncrakes (Keišs 2005, Koffijberg \& Schäffer 2006, Bíró et al. 2013). However, there are different kinds of subsidies within agri-environment measures, and some, such as the High Nature Value Area programmes, were introduced to maintain Corncrake-friendly management regimes in grasslands (European Commission 2005, Sztahura \& Rezneki 2015). However, finding measures that are both beneficial for the Corncrake and other grassland birds and profitable to farmers in agricultural areas is complicated and difficult (Kleijn et al. 2004, Berg \& Gustavson 2007, Beaumont \& England 2016). The administrative systems of subsidies are rigid and limited to defined areas and periods, however, the habitat use of Corncrakes is not. The long-distance movements of Corncrakes within a breeding season have been known for a long time (Bürger et al. 1998, Koffijberg \& van Dijk 2001, Schäffer \& Koffijberg 2004, Koffijberg et al. 2016), and this knowledge can be used for the designation of subsidised areas. These movements can also be triggered by floods, which have particular importance in the Carpathian Basin. If Corncrakes move from protected and/or subsidised areas threatened by floods to unfavourable breeding sites, such movements will have an important implication for Corncrake conservation. The Corncrake is an umbrella species as its protection covers other species of wet meadows (e.g. Wettstein \& Szép 2003, Boldogh et al. 2016). In Hungary, three agri-environmental packages have measures that are relevant to Corncrakes within the Rural Development Programme (2015-2020) (Boldogh et al. 2016). These include the "bird-friendly mowing", the "delayed mowing" and the "keeping unmown area" measures, which can be beneficial to the Corncrake, and obviously for other protected species (Green et al. 1997, Stowe \& Green 1997, Beaumont \& England 2016).

The main aims of this study were to (i) identify interlinkages among major Corncrake breeding sites in north-east Hungary, (ii) improve our interpretation of monitoring data on a national and regional scale, and (iii) to draw attention to the vulnerability of the most important breeding sites of Corncrakes in Hungary. Our general aim was to provide input for nature conservation authorities for the adequate designation of High Nature Value Grassland Areas and other protected sites.

\section{Material and Methods}

We surveyed populations of Corncrakes between 1997-2000 and 2003-2006 at four sites in NE Hungary (total $1475.3 \mathrm{~km}^{2}$ ) (Figure 1), following international guidelines and methods (Sheppard \& Green 1994, Schäffer \& Mammen 2003). Previous results suggested that 
the most important breeding sites of the species were in this part of the country (Szép 1991, Boldogh 1999, Boldogh \& Szentgyörgyi 2003).

Censuses of singing Corncrakes in the potential breeding habitats were conducted at night (23:00-03:30) throughout the breeding season (15 May-30 June). Data from surveys conducted before $15^{\text {th }}$ May were excluded from the analyses to avoid overlap with the migration of birds. Most of the surveys were completed by mid-June, thus, the subsequent increase in the number of displaced males did not influence our results. We aimed to survey all suitable breeding sites regardless of their management regime or protection status and strived for similar sampling effort in all sites and years. In a single survey, c. $70-80 \%$ of the singing males can be recorded, hence 2-3 visits per site are recommended (Schäffer \& Mammen 2003). Accordingly, we surveyed $75 \%$ of the study area at least twice and $15 \%$ of the area at least three (or more, up to six) times. Generally, at least five days passed between subsequent surveys. If a singing male was found less than $200 \mathrm{~m}$ apart at the same site during a subsequent survey, it was treated as the same individual. We inferred one territory when the same individual was heard at the same site subsequently on at least two (but often more, up to six) survey occasions. The location of calling males was determined by GPS or recorded on 1:25000 and 1:10 000 topographic maps.

The first site, the Aggtelek National Park and its surroundings (Aggtelek NP in Figure 1), is $1160 \mathrm{~km}^{2}$. Dominant natural and semi natural habitats in the area are deciduous forests (e.g. Quercetum petraeae-cerris, Querco petraeae-Carpinetum) and different grasslands (55\% and 13\%, respectively). Arable lands cover 30\%. The most important breeding habitats are wet meadows (e.g. Caricetum acutiformis-ripariae, Cirsio cani-Festucetum

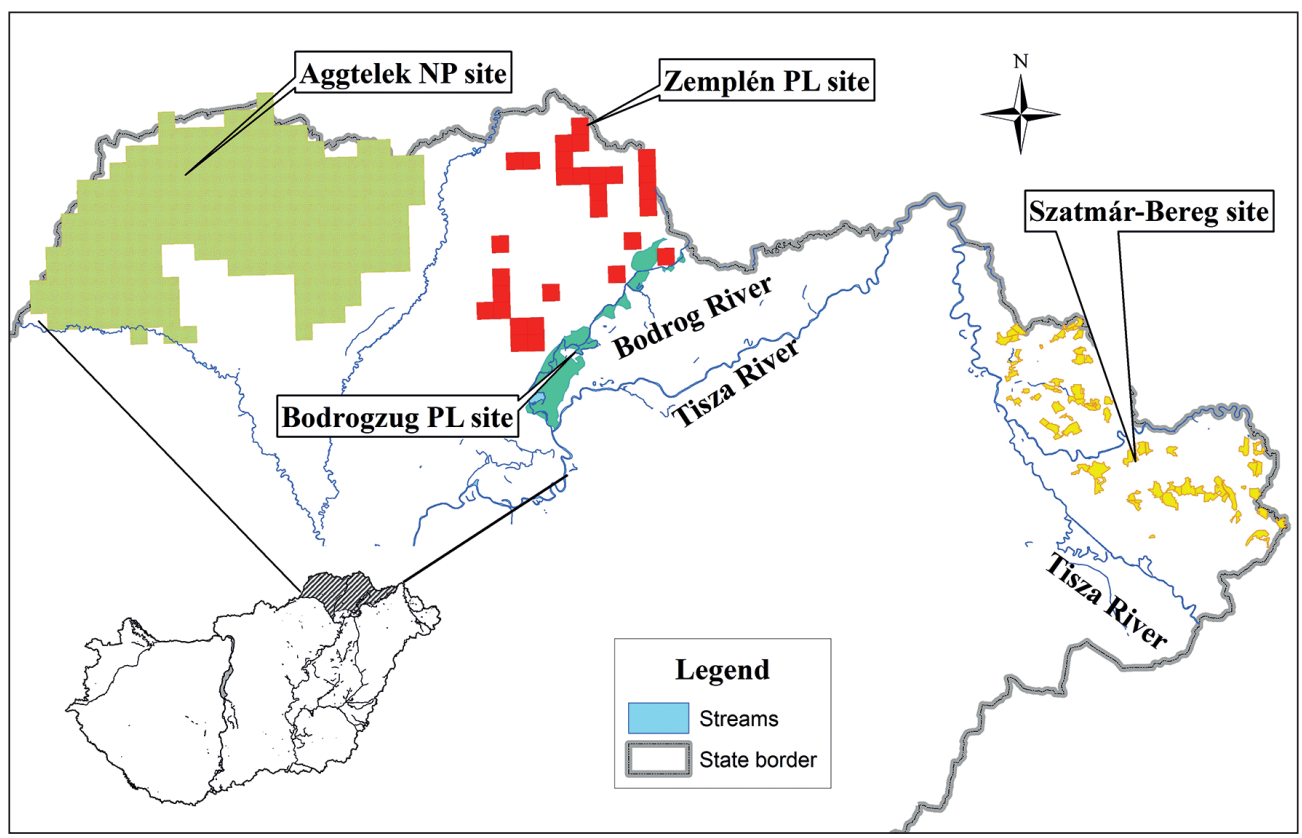

Figure 1. The distribution of the study sites in NE Hungary 1. ábra A vizsgálati helyszínek Északkelet-Magyarországon 
pratensis) and abandoned pastures (Boldogh \& Szentgyörgyi 2003) in the small river valleys (e.g. Szuha, Bódva valley). Most meadows are abandoned and overgrown with high vegetation, and less than $20 \%$ of the grasslands are managed. Flooding of the breeding habitats is infrequent and is restricted to small areas (Marosi \& Somogyi 1990). Parts of the site are protected as Aggtelek NP $\left(200 \mathrm{~km}^{2}\right)($ Homepage of the Hungarian State Nature Conservancy 2016).

The second site covers $125 \mathrm{~km}^{2}$ in the Zemplén Mountains (Zemplén PL in Figure 1) and involves wet meadows mainly along small streams (e.g. Bózsva, Bényei). A large portion of the site is covered by wet meadows (e.g. Agrostio-Deschampsietum caespitosae, Angelico-Cirsietum olerace) and arable lands (60\% and $15 \%$, respectively). The majority of the meadows are unmanaged (not grazed or mowed). Floods are very rare here. Parts of the site are included in the Zemplén Landscape Protection Area (Homepage of the Hungarian State Nature Conservancy 2016).

The third site, the Bodrogzug and Bodrogmente, consists of $90.5 \mathrm{~km}^{2}$ in the flood-plain of rivers Bodrog and Tisza (Bodrogzug PL in Figure 1). Riparian meadows (e.g. Alopecuretum pratensis, Agrostetum albae) and marshes are the dominant habitat types ( $70 \%$ and $15 \%$, respectively). The intensity of management is moderate as less than $30 \%$ of the grasslands are managed, mainly used for mowing and grazing ( $80 \%$ and $20 \%$, respectively). The threat of flooding is high (Marosi \& Somogyi 1990). In years with high water level, $20-100 \%$ of the site is flooded mainly from April to June. This site is of great conservation interest because of breeding and migrating birds, therefore, it is protected and included in the Ramsar Convention of Wetlands (Tardy 2007) (Homepage of the Hungarian State Nature Conservancy 2016).

The fourth site, the Szatmár-Bereg lowland, is in the easternmost part of Hungary between rivers Tisza and Szamos, and consists of $99.8 \mathrm{~km}^{2}$ (Szatmár-Bereg in Figure 1). Different grasslands (e.g. Agrostetum albae, Alopecuri-Festucetum pseudovinae) cover the whole territory (Wettstein et al. 2001, Wettstein \& Szép 2003). Many are abandoned due to the decreasing number of livestock. A considerable part of the site is a floodplain of river Tisza and its tributaries. Parts of the site are protected as the Szatmár-Bereg Landscape Protection Area (Homepage of the Hungarian State Nature Conservancy 2016).

We studied the observed fluctuations of Corncrake populations at the four sites between 1997 and 2006, with the exception of 2001 and 2002, when surveys were not carried out at the Zemplén PL and Bodrogzug PL. We analysed the changes in the number of territories at the four sites in eight years and as a function of water level, using generalised least squares regression (function ' $\mathrm{gls}$ ' in $\mathrm{R}$ package 'nlme'). This allows the specification of an autocorrelation structure, which, in our case, involved temporal (between-year) autocorrelation in the number of territories within sites (grouping factor). We characterised water levels by the maximum water level reading of river Tisza, measured at the checkpoint of Tokaj, during the settlement and breeding period of Corncrakes (April-May). We used the ArcMap 9.2 GIS software for determining the High Nature Value Programme status of the breeding sites and visualizing the results of the evaluation. All statistical analyses were performed in the R statistical environment (version 3.2.2, R Core Team 2015). 


\section{Krajnyák \& Sz. Lengyel}

\section{Results}

In total, $4194(100 \%)$ territories with singing Corncrakes were recorded at the study sites during 8 years. One thousand two hundred and fifty-seven (30\%) Corncrake territories were at the Aggtelek NP site, 777 (18.5\%) at the Zemplén PL site, 1281 (30.5\%) at Bodrogzug PL site and 879 (21\%) in the Szatmár-Bereg site (Table 1). The total number of territories on the four sites fluctuated between 407 and 631 territories between 1997 and 2000, and between 427 and 580 territories between 2003 and 2006 (Table 1), and did not differ between the two time periods (mean \pm S.D., period 1: $544.5 \pm 96.35$, period 2: $504.0 \pm 68.86 ; \mathrm{t}_{6}=0.684$, $\mathrm{p}=0.520)$.

The number of territories was relatively stable between 1997 and 2000 in the Bodrogzug, Szatmár-Bereg and Zemplén sites and decreased in the Aggtelek site (Figure 2). In contrast with the last four years (2003-2006), Corncrakes have almost completely disappeared from the Bodrogzug site, while the number of territories increased five-fold in the Zemplén PL site, three-fold in Aggtelek NP, and two-fold in the Szatmár-Bereg site (Figure 2). The generalised least squares regression showed a significant interaction between site and maximum water level of river Tisza in April-May $\left(F_{3,24}=4.846, p=0.009\right)$, indicating that the relationship between Tisza water level and number of territories differed among the sites. This was because the relationship was negative for the Bodrogzug site and generally positive for the three other sites (Figure 3).

The number of territories in the Bodrogzug PL site strongly depended on maximum water level of river Tisza in April-May. If the water level of river Tisza at Tokaj exceeds 550 $\mathrm{mm}$ (c. $95 \mathrm{~m}$ above sea level), more than $80 \%$ of the Bodrogzug area is inundated, whereas the entire Bodrogzug area is inundated if water level on river Tisza exceeds $600 \mathrm{~mm}$ (Figure 4) (Vass 2014, Szabó et al. 2016). In flood years, the water levels were much higher than these values. For example, the maximum water level at Tokaj was $847 \mathrm{~cm}$ in 2001 . When

Table 1. The number of territories estimated based on the presence of singing Corncrakes in the four study sites in NE Hungary in 1997-2006 (surveys were incomplete in 2001 and 2002). For details of different sites, please see Materials and methods

1. táblázat A haris territóriumok száma a harsogó hímek száma alapján az egyes mintaterületeken Északkelet-Magyarországon 1997-2006 között (2001-ben és 2002-ben a felmérések nem minden mintaterületen történtek meg). Az egyes területek leírása az Anyag és módszerek részben szerepel

\begin{tabular}{|l|c|c|c|c|}
\hline Year & Aggtelek NP & Bodrogzug PL & Szatmár-Bereg & Zemplén PL \\
\hline 1997 & 134 & 232 & 125 & 88 \\
\hline 1998 & 216 & 238 & 96 & 81 \\
\hline 1999 & 143 & 215 & 133 & 70 \\
\hline 2000 & 47 & 199 & 81 & 80 \\
\hline 2003 & 84 & 228 & 78 & 37 \\
\hline 2004 & 140 & 158 & 70 & 101 \\
\hline 2005 & 233 & 10 & 162 & 135 \\
\hline 2006 & 260 & 1 & 134 & 185 \\
\hline
\end{tabular}




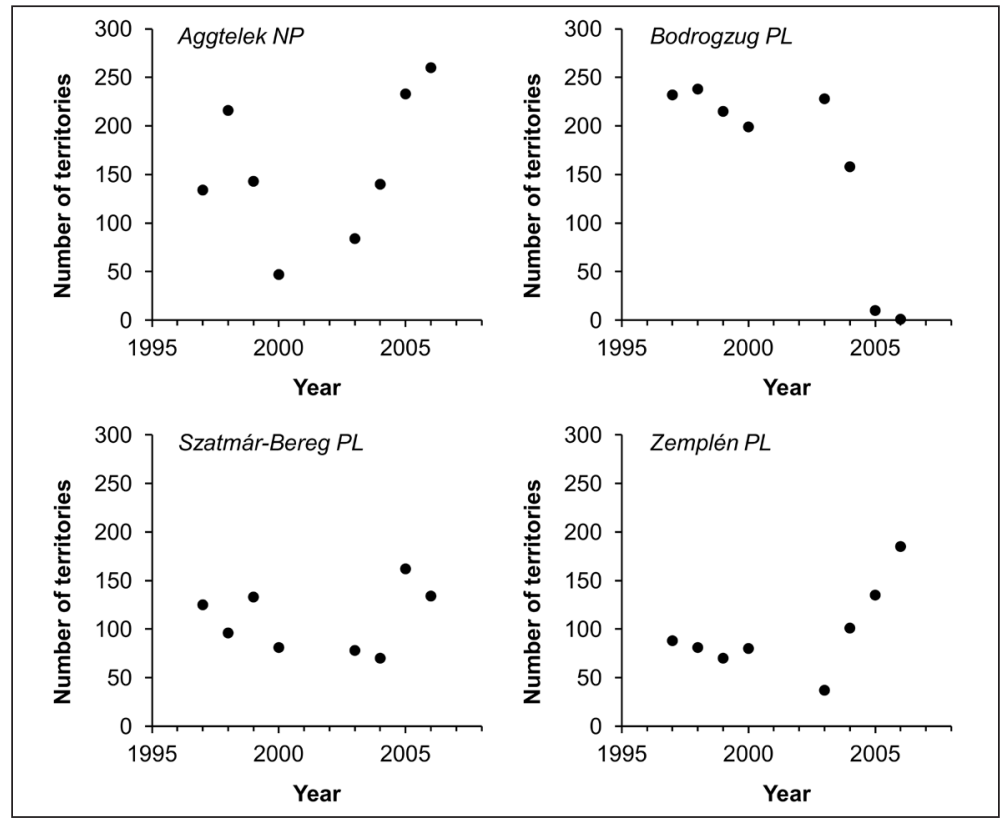

Figure 2. Number of Corncrake territories at the four study sites in the eight study years 2. ábra A haris-territóriumok száma a négy vizsgálati területen a nyolc felmért évben

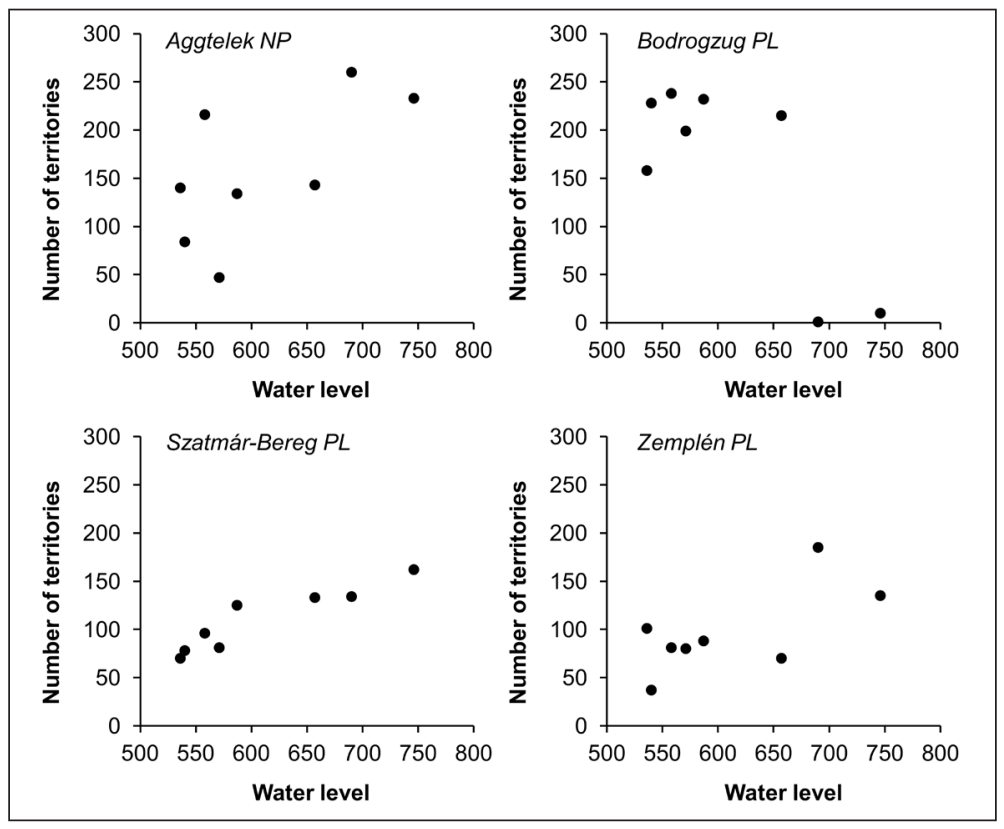

Figure 3. Number of Corncrake territories as a function of maximum water level of river Tisza at Tokaj in April-May (in cm) of each year

3. ábra A haris-territóriumok száma a Tokajnál április-májusban mért maximális vízállás $(\mathrm{cm})$ függvényében 


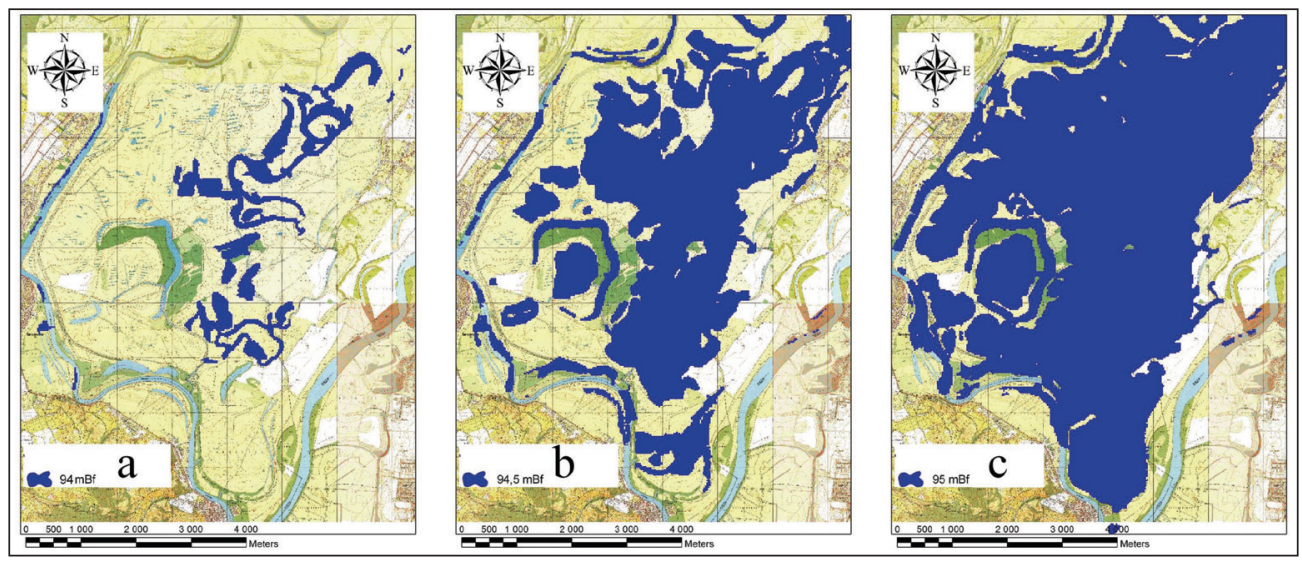

Figure 4. Area (in blue) inundated in the Bodrogzug PL site when the water level of river Tisza at Tokaj is at $94.0 \mathrm{~m} \mathrm{(a)}, 94.5 \mathrm{~m} \mathrm{(b)}$ and $95 \mathrm{~m} \mathrm{(c)} \mathrm{above} \mathrm{sea} \mathrm{level.} \mathrm{Source} \mathrm{(a-c):} \mathrm{G.} \mathrm{Molnár} \mathrm{after} \mathrm{the}$ ÉKÖVIZIG (Miskolc) database

4. ábra. A Tisza által elöntött terület (kékkel) a Bodrogzugi TK területén, amikor a Tisza vízszintje eléri a 94 m-es (a), a 94,5 m-es (b) és a 95 m-es (c) tengerszint feletti szintet. Forrás (a-c): Molnár G. az ÉKÖVIZIG (Miskolc) adatai alapján

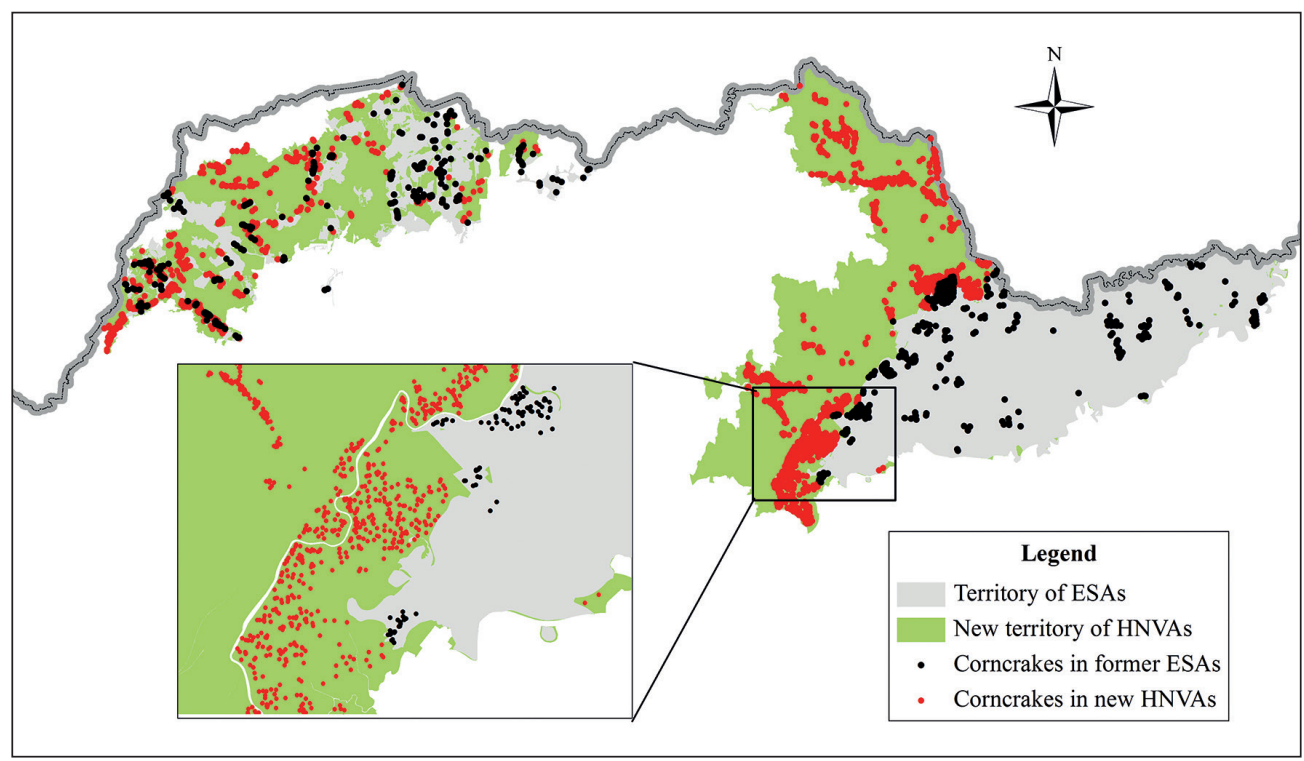

Figure 5. Distribution of Corncrake territories based on singing males observed during 1997-2006 in the previously designated subsidised territories (ESAs) and the enlargement of areas included under the High Nature Value Areas programme with consideration to the largescale redistribution patterns of Corncrakes in NE Hungary

5. ábra A haris-territóriumok eloszlása az éneklő hímek alapján 1997 és 2006 között a korábbi agrártámogatási rendszer (ESA) területén, és a támogatási rendszerbe a Magas Természeti Érzékenységű Területek programon át újonnan, a haris újraeloszlási mintázatának figyelembevételével bevont területeken Északkelet-Magyarországon 
the maximum April-May water level was above $660 \mathrm{~m}$ in 2005 and 2006, Corncrakes almost disappeared from the site (Figure 2). In addition, in 2006, a long and intense flood in April (maximum level: $892 \mathrm{~cm}$ ) was followed by a "green" flood in late May and early June. These years also showed large increases of the nesting population in the Aggtelek, Szatmár-Bereg and Zemplén sites, and the increase was greatest at the Zemplén site (Figure 2), which is closest to the Bodrogzug site (Figure 1).

Finally, none of the most abundant breeding sites was covered by any agri-environment subsidy schemes (e.g. ESA) until 2009 (Figure 5). However, the extension of HNVAs efficiently covered Corncrake breeding sites at three of the sites studied (Figure 5).

\section{Discussion}

The studied areas in NE Hungary hold the most important local Corncrake populations in the country (Boldogh et al. 2009, 2016), which are also remarkable even in an international context (Koffijberg et al. 2016). The sizes of the local populations fluctuate considerably, which was also reported for other populations of the breeding range (e.g. Keišs 2003, Sukhanova \& Mischenko 2003, Schäffer \& Koffijberg 2004, Schoppers \& Koffijberg 2006, Koffijberg et al. 2016). However, our study is the first to report both concerted changes (period between 1997-2000) and negative correlations (period between 2003-2006) in the sizes of the local populations. In time period 2, population declines in the Bodrogzug PL site were in concert with population increases in the other local populations. Our results suggest that the different inter-population relationships between time period 1 (when only small floods occurred) and time period 2 (when extended floods occurred) may be explained by the flood characteristics of river Tisza. The negative correlation between local population size at Bodrogzug PL site and maximum water level of Tisza River indicates that the higher the flood level, the less area is available for birds to nest in this site. The contrasting patterns between Bodrogzug PL site (population decline) and the other three local populations (population increases) suggest that many of the birds that had been driven out from the floodplain meadows at Bodrogzug PL site appeared in the other parts of the studied area in the years with inundation (time period 2). Unfortunately, there are no bird ringing results to confirm the movement of individuals between sites.

Factors triggering long-distance movements and distribution of Corncrakes within one breeding season are poorly revealed (Koffijberg et al. 2016), although searching for suitable breeding sites for a second brood and/or after disturbance by mowing might initiate such movements (Green et al. 1997, Schäffer \& Koffijberg 2004). Our study provides a good example of the direct effect of flood on Corncrake distribution in Hungary, a phenomenon that has been suggested to operate on a much larger scale in some other parts of Europe (Mischenko \& Sukhanova 1999, Koffijberg \& van Dijk 2001). Due to the large mobility of Corncrakes within and between breeding seasons (e.g. van den Bergh 1991, Bürger et al. 1998, Koffijberg et al. 2016), floods may have an impact on geographically distant Corncrake populations, especially when they affect large numbers of Corncrakes, e.g. in the core breeding areas in Russia. For instance, Koffijberg and van Dijk (2001) assumed in their study 


\section{Krajnyák \& Sz. Lengyel}

that the influx of Corncrakes in the Netherlands in 1998 was due to immigration from Belorussian and Russian populations, where the high water tables and floods hindered breeding in the floodplains. Similar effects of distant floods could also not be excluded in Hungary (Boldogh et al. 2009). Our results confirm that local populations need to be monitored simultaneously (all sites in all years), and they also suggest that the data from monitoring of the local populations have to be evaluated with consideration to their interrelationships.

Our study also shows that floods can have contrasting effects on Corncrake populations. On one hand, floods often have important positive effects on maintaining suitable vegetation at the breeding sites (Schäffer \& Koffijberg 2004), and can delay the start of mowing that may threaten nests in floodplain meadows. On the other hand, a delayed retreat of floodwaters may be disadvantageous for Corncrakes, because this species prefers and tolerates much drier habitats than other Rallidae (Schäffer 1999). Our results show that this can happen in different years at the most important breeding site in Hungary (Bodrogzug PL site, time period 2). Long periods of flooding at this site are partly a result of human activities (Figure 3). Due to the impact of a hydroelectric dam at Tiszalök, the retreat of floods is 2-2.5 times slower in this section of the river than in upper or lower reaches. Our data show that the dense, concentrated local populations of Corncrakes, as well as the populations of other grassland birds, are highly vulnerable to floods and other threats in this part of the floodplain. In fact, in years of flooding, the birds can not find breeding places here at all, or they have to move elsewhere, presumably leaving behind their nests.

This pattern of redistribution should be considered in designing Corncrake conservation measures in the region. Our data suggests that in order to reduce the negative impact of floods and improve protection of Corncrakes, it is highly important to maintain suitable alternative breeding places outside floodplains. Because the intensity and the methods of land use are key issues in the conservation of Corncrake populations (Green \& Rayment 1996, Schäffer \& Green 2001, Schäffer \& Koffijberg 2004), the extension of favourable grassland management (e.g. Schäffer \& Weisser 1996, Green et al. 1997) to the unprotected and unsupported areas is justified by our results. According to recent studies (e.g. O'Brien et al. 2006, Beaumont \& England 2016), the conservation management schemes have clear benefits to Corncrakes. The implementation of allowance guidelines and measures (c.f. Sztahura \& Rezneki 2015) that enable Corncrake-friendly management on HNVAs (e.g. supervising by national park directorates, delayed mowing, obligatory use of game-repellent chains when mowing, adequate mowing directions, leaving unmown areas) would likely lead to a more favourable conservation status of Corncrakes (Faragó \& Szentirmai 2014, Boldogh et al. 2016). Our results also implicitly suggest that an extension of the areas managed in bird-friendly ways and subsidised under the HNVA programme was necessary in NE Hungary for the effective protection of Corncrakes. Previously, less than $25 \%$ of known Corncrakes were in ESAs in different years (Boldogh et al. 2009), whereas this number increased to about $70 \%$ after the redesign and enlargement of this area by 35000 ha in the HNVA programme (Figure 4). We believe that the extension will be a significant step forward in Corncrake conservation in NE Hungary.

Our results also suggest that further direct human impacts (e.g. building of a new dam on river Bodrog) and climate change may have serious negative impacts on Corncrakes 
in the studied region and in Hungary. Climate change projections suggest a complete restructuring of the annual distribution of precipitation, as well as an increase in heavy precipitation events and severely increased peak river discharges and floods (Christensen \& Christensen 2004, Bartholy et al. 2007, Kyselý \& Beranová 2008, Bartholy et al. 2009, Rakonczai 2011). Therefore, the breeding possibilities of Corncrakes may become more limited in riparian meadows in the future. Hence, the importance of suitable breeding habitats outside flood-affected areas will probably grow in the near future and these habitats thus deserve an adequate conservation strategy. This is also because there is a risk that many of these grasslands will be converted to arable lands or will be abandoned and exposed to succession and invasive plants, which will generate conditions that are suitable neither for diverse wildlife nor for Corncrakes.

\section{Acknowledgements}

We thank Kees Koffijberg and Katalin Csilléry whose constructive comments improved an earlier version of the manuscript. Special thanks to Géza Molnár for his data, figures and information on floodings. We are also grateful to J. Balogh, P. Barcánfalvi, Cs. Bartha, I. Béres, T. Burinda, S. Ebesfalvi, R. Farkas, G. Firmánszky, F. Halmos, K. Homoki, A. Huber, P. Hunyadvári, J. Juhász, T. Juhász, A. Kálmán, Zs. Kanyok, A. Kelemen, A. Korpás, K. Kovács, I. Márkus, I. Mihalik, A. Mócsán, Z. Petrovics, B. Pingitzer, J. Serfőző, I. Szólláth, F.B. Szüts, Zs. Tolnay, L. Trungel, R. Vadnay, K. Varjasy, P. Veres, T. Vizslán and W. Wettstein $\uparrow$ for their help during the field surveys. We acknowledge the Aggtelek National Park Directorate and BirdLife Hungary (MME) for permitting and funding this work. The data of water levels on the Tisza River were provided by the Upper Tisza Environment and Water Directorate (FETIKÖVIZIG, Nyíregyháza) and the Northern Hungarian Environment and Water Directorate (ÉKÖVIZIG, Miskolc). We thank Andrea Harnos for suggestions on statistics and two anonymous reviewers for comments on an earlier draft. The study was partly supported by the Jedlik Ányos Programme (NKFP6-00059/2005) to the Gömör-Torna Working Group of MME BirdLife Hungary, and by a grant from OTKA (K106133) to SL. 


\author{
C. Krajnyák \& Sz. Lengyel
}

\title{
References
}

Bartholy, J., Pongrácz, R. \& Gelybó, Gy. 2007. Regional climate change expected in Hungary for 2071-2100. Applied Ecology and Environmental Research 5(1): 1-17. DOI: 10.15666/aeer/0501_001017

Bartholy, J., Pongrácz, R., Torma, Cs., Pieczka, I., Kardos, P. \& Hunyady, A. 2009. A comparison of observed trends and simulated changes in extreme climate indices in the Carpathian basin by the end of this century. International Journal of Global Warming 1: 238-252. DOI: 10.1504/IJGW.2009.027092

Beaumont, D. J. \& England, B. J. 2016. The Corncrake Crex crex population in Scotland from 1993 to 2015 with an overview of conservation measures taken during this period. - Vogelwelt 136: 153-161.

Benton, T. G., Bryant, D. M., Cole, L. \& Crick, H. Q. P. 2002. Linking agricultural practice to insect and bird populations: a historical study over three decades. - Journal of Applied Ecology 39: 673-687. DOI: 10.1046/j.1365-2664.2002.00745.x

Berg, A. \& Gustavson, T. 2007. Meadow management and occurrence of Corncrake Crex crex. - Agriculture, Ecosystems and Environment 120: 139-144. DOI: 10.1016/j.agee.2006.08.009

Bíró, M., Czúcz, B., Horváth, F., Révész, A., Csatári, B. \& Molnár, Zs. 2013. Drivers of grassland loss in Hungary during the post-socialist transformation (1987-1999). - Landscape Ecology 28(5): 789-803. DOI: 10.1007/ s10980-012-9818-0

Boldogh, S. 1999. The Corncrake (Crex crex L. 1758) in Hungary. - In: Schäffer, N. \& Mammen, U. (eds.) Proceedings of the International Corncrake Workshop, Hilpolstein (Germany). - www.corncrake.net/proceedings.htm (downloaded on: 11.02.2016)

Boldogh, S. \& Szentgyörgyi, P. 2003. A haris (Crex crex) állományának vizsgálata az Aggteleki Nemzeti Park Igazgatóság illetékességi területén 1997-2002 között [Research on Corncrake (Crex crex L. 1758) in the administrative area of Aggtelek N. P. (N. Hungary) between 1997 and 2002]. - ANP Füzetek 2: 77-96. (in Hungarian)

Boldogh, S., Szegedi, Z., Szentgyörgyi, P. \& Petrovics, Z. 2009. Distribution, population size and conservation of Corncrake Crex crex in North-east Hungary, 1997-2006. - Vogelwelt 130: 153-158.

Boldogh, S., Szentirmai, I., Nagy, K. \& Habarics, B. 2016. Distribution, population trends and conservation status of the Corncrake (Crex crex) in Hungary, 2007-2015. - Vogelwelt 136: 121-126.

Bürger, P., Pykal, J. \& Hora, J. 1998. Rozsírení, pocetnost a vysledky krouzkování chrástala polního (Crex crex) v Ceské republice v letech 1993-1997 [Distribution, numbers and ringing results of Corncrake (Crex crex) in the Czech Republic in the period 1993-1997]. - Sylvia 34: 73-84. (in Czech with English Summary)

Chamberlain, D. E., Fuller, R. J., Bunce, R. G. H., Duckworth, J. C. \& Shrubb, M. 2000. Changes in the abundance of farmland birds in relation to the timing of agricultural intensification in England and Wales. - Journal of Applied Ecology 37: 771-788. DOI: 10.1046/j.1365-2664.2000.00548.x

Christensen, O. B. \& Christensen, J. H. 2004. Intensification of extreme European summer precipitation in a warmer climate. - Global and Planetary Change 44: 107-117. DOI: 10.1016/j.gloplacha.2004.06.013

Crockford, N. J., Green, R. E., Rocamora, G., Schäffer, N., Stowe, T. J. \& Williams, G. 1996. Corncrake. - In: Heredia, B. L., Rose, L. \& Painter, M. (eds.) Globally Threatened Birds in Europe: Action Plans. - Council of Europe, Bruxelles

Donald, P. F., Green, R. E. \& Heath, M. F. 2001. Agricultural intensification and the collapse of Europe's farmland bird populations. - Proceedings of the Royal Society of London B. 268: 25-29. DOI: 10.1098/rspb.2000.1325

Donald, P. F., Sanderson, F. J., Burfield, J. \& van Bommel, F. P. J. 2006. Further evidence of continent-wide impacts of agricultural intensification on European farmland birds, 1990-2000. - Agriculture, Ecosystems and Environmental 116: 189-196. DOI: 10.1016/j.agee.2006.02.007

Elts, J. 1997. Studies of the Corncrake in Estonia in 1995. - Vogelwelt 118: 236-238.

European Commission 2005. Agri-environment Measures. Overview on General Principles, Types of Measures, and Application. - European Commission, Directorate General for Agriculture and Rural Development, Bruxelles

European Environment Agency 2007. The Pan-European Environment: Glimpses Into An Uncertain Future. EEA Report No 4/2007. Copenhagen

Faragó, Á. \& Szentirmai, I. 2014. Az őrségi harisok (Crex crex) élőhely-használatának kutatása rádió-telemetriás nyomkövetés segítségével [Research on the habitat selection of the Corncrake (Crex crex) in Örség, using radio-telemetry]. - Cinege 19: 17-23. retrieved from: http://chernelmte.extra.hu/cinege2014_19_teljes.pdf

Green, R. E. 1995. The decline of Corncrake Crex crex in Britain continues. - Bird Study 42: $\overline{6} 6-75$. DOI: $10.1080 / 00063659509477150$ 
Green, R. E. \& Rayment, M. D. 1996. Geographical variation in the abundance of the Corncrake Crex crex in Europe in relation to the intensity of agriculture. - Bird Conservation International 6: 201-211. DOI: 10.1017/ S0959270900003105

Green, R. E., Rocamora, G. \& Schäffer, N. 1997. Populations, ecology and threats to the Corncrake Crex crex in Europe. - Vogelwelt 118: 117-134.

Henle, K., Alard, D., Clitherow, J., Cobb, P., Firbank, L., Kull, T., McCracken, D., Moritz, R. F. A., Niemelä, J., Rebane, M., Wascher, D., Watt, A. \& Young, J. 2008. Identifying and managing the conflicts between agriculture and biodiversity conservation in Europe - A review. - Agriculture, Ecosystem and Environment 124: 60-71. DOI: 10.1016/j.agee.2007.09.005

Homepage of the Hungarian State Nature Conservancy 2016. A védett természeti területek és értékek csoportosítása [The classification and catalogue of protected natural areas and values]. - http://www.termeszetvedelem.hu/a-vedett-termeszeti-teruletek-es-ertekek-csoportositasa (last accessed: 26.09.2016) (in Hungarian)

Hopkins, A. \& Holz, B. 2006. Grassland for agriculture and nature conservation: production, quality and multi-functionality. - Agronomy Research 4(1): 3-20.

Keišs, O. 1997. Results of randomised Corncrake Crex crex survey in Latvia 1996: population estimates and habitat selection. - Vogelwelt 118: 231-235.

Keišs, O. 2003. Recent increases in numbers and the future of Corncrake Crex crex in Latvia. - Ornis Hungarica 12-13: 151-156.

Keišs, O. 2005. Impact of changes in agricultural land use on the Corncrake Crex crex population in Latvia. - Acta Universitatis Latviensis (Biology) 691: 93-109.

Keišs, O., Granāts, J. \& Mednis, A. 2007. Estimated population dynamics of the Corncrake Crex crex in Latvia and Europe in the $20^{\text {th }}$ century by ringing data analysis. - Acta Universitatis Latviensis (Biology) 723: 71-97.

Kleijn, D., Berendse, F., Smit, R., Gilissen, N., Smit, J., Brak, B. \& Groeneveld, R. 2004. Ecological effectiveness of agri-environment schemes in different agricultural landscapes in the Netherlands. - Conservation Biology 18: 775-786. DOI: 10.1111/j.1523-1739.2004.00550.x

Kleijn, D., Kohler, F., Báldi, A., Batáry, P., Concepción, E. D., Clough, Y., Díaz, M., Gabriel, D., Holzschuh, A., Knop, E., Kovács, A., Marshall, E. J. P., Tscharntke, T. \& Verhulst, J. 2009. On the relationship between farmland biodiversity and land-use intensity in Europe. - Proceedings of the Royal Society B, Biological Sciences 276: 903-909. DOI: 10.1098/rspb.2008.1509

Koffijberg, K. \& Schäffer, N. (compilers). 2006. International Single Species Action Plan for the Conservation of the Corncrake Crex crex. - CMS Technical Series No. 14 and AEWA Technical Series No. 9. Bonn, Germany

Koffijberg, K. \& van Dijk, A. J. 2001. Influx van Kwartelkoningen Crex crex in Nederland in 1998. [Influx of Corncrakes Crex crex in the Netherlands in 1998]. - Limosa 74: 147-159. (in Dutch with English Summary)

Koffijberg, K., Hallman, C., Keišs, O. \& Schäffer, N. 2016. Recent population status and trends of Corncrakes Crex crex in Europe. - Vogelwelt 136: 75-87.

Kyselý, J. \& Beranová, R. 2008. Climate-change effects on extreme precipitation in central Europe: uncertainties of scenarios based on regional climate models. - Theoretical and Applied Climatology, 95(3): 361-374. DOI: 10.1007/s00704-008-0014-8

Marosi, S. \& Somogyi, S. 1990. Magyarország kistájainak katasztere I-II. [Micro-regions in Hungary I-II.]. MTA Földtudományi Kutató Intézet, Budapest (in Hungarian)

Mischenko, A. L. \& Sukhanova, O. V. 1999. Corncrake Crex crex in European Russia: Methods and results of a large-scale census. - Vogelwelt 120(Suppl.): 323-327.

O’Brien, M., Green, R. E. \& Wilson, J. 2006. Partial recovery of the population of Corncrakes Crex crex in Britain, 1993-2004. - Bird Study 53: 213-224. DOI: 10.1080/00063650609461436

Pe'er, G., Dicks, L. V., Visconti, P., Arlettaz, R., Báldi, A., Benton, T. G., Collins, S., Dieterich, M., Gregory, R. D., Hartig, F., Henle, K., Hobson, P. R., Kleijn, D., Neumann, R. K., Robijns, T., Schmidt, J., Shwartz, A., Sutherland, W. J., Turbé, A., Wulf, F. \& Scott, A. V. 2014. EU agricultural reform fails on biodiversity. - Science 344(6188): 1090-1092. DOI: 10.1126/science.1253425

R Core Team 2015. R: A language and environment for statistical computing. R Foundation for Statistical Computing, Vienna, Austria. https://www.R-project.org_(last accessed: 19.11.2016)

Rakonczai, J. 2011. Effects and Consequences of Global Climate Change in the Carpathian Basin. - In: Blanco, J. (ed.) Climate Change - Geophysical Foundations and Ecological Effects, (retrieved from: http://www. intechopen.com/books/climate-change-geophysical-foundationsand-ecological-effects/effects-and-consequences-of-global-climate-change-in-the-carpathian-basin on 20.08.2016), pp. 297-322. 


\section{Krajnyák \& Sz. Lengyel}

Schäffer, N. 1999. Habitatwahl und Partnerschftssystem von Tüpfelralle Porzana porzana und Wachtelkönig Crex crex [Habitat use and mating systems of the Corncrake and Spotted Crake]. - Ökologie der Vögel 21: 1-267. (in German)

Schäffer, N. \& Green, R. E. 2001. The global status of the Corncrake. - RSPB Conservation Review 13: 18-24.

Schäffer, N. \& Koffijberg, K. 2004. Corncrake (Crex crex). - Birds of Western Palearctic, Update 6(1-2): 55-76.

Schäffer, N. \& Mammen, U. 2003. International Corncrake monitoring. - Ornis Hungarica 12-13: 129-133.

Schäffer, N. \& Weisser, W. W. 1996. Modell für den Schutz des Wachtelkönigs Crex crex [A strategy for the conservation of the Corncrake Crex crex]. - Journal of Ornithology 137: 53-75. DOI: 10.1007/BF01651499 (In German with English Summary)

Schoppers, J. \& Koffijberg, K. 2006. Kwartelkoningen in Nederland in 2005. - SOVON-informatierapport 2006/01. SOVON Vogelonderzoek Nederland, Beek-Ubbergen

Sheppard, R. \& Green, R. E. 1994. Status of the Corncrake in Ireland in 1993. - Irish Birds 5: 125-138.

Stowe, T. J. \& Green, R. E. 1997. Response of Corncrake Crex crex populations in Britain to conservation actions. - Vogelwelt 112: 161-168.

Sukhanova, O. V. \& Mischenko, A. L. 2003. Monitoring Corncrake Crex crex numbers in European Russia: the first stage. - Ornis Hungarica 12-13: 135-141.

Suttie, J. M., Reynolds, S. G. \& Batello, C. (eds.) 2005. Grassland of the World. - Plant Production and Protection Series No. 34. Food and Agriculture Organization of the United Nations, Rome

Szabó, J., Vass, R., Félegyházi, E. \& Tóth, C. 2016. A bodrogzugi ártér felszínfejlődési tendenciái [Surface development trends of the Bodrogzug floodplain]. - Acta Climatologica et Chorologica 50/B: 105-113. (in Hungarian)

Szép, T. 1991. The present and historical situation of the Corncrake in Hungary. - Vogelwelt 112: 45-48.

Sztahura, E. \& Rezneki, R. (eds.) 2015. Agrár-Környezet-Gazdálkodás - Kézikönyv a támogatási kérelem benyújtásához [Agri-Environmental-Management - Handbook to the submission of the support application]. Nemzeti Agrárgazdasági Kamara, Budapest (in Hungarian)

Tardy, J. (ed.) 2007. A magyarországi vadvizek világa (Hazánk ramsari területei) [Ramsar sites of Hungary]. Alexandra Kiadó, Pécs (in Hungarian)

van den Bergh, L. 1991. Status, distribution and research on Corncrakes in the Netherlands. - Vogelwelt 112: $78-83$.

Vass, R. 2014. Ártérfejlődési vizsgálatok felső-tiszai mintaterületeken [Investigation of floodplain development at study areas in the Upper-Tisza region]. - PhD Thesis, University of Debrecen (in Hungarian)

Wettstein, W. \& Szép, T. 2003. Status of the Corncrake Crex crex as an indicator of biodiversity in Eastern Hungary. - Ornis Hungarica 12-13: 143-149.

Wettstein, W., Szép, T. \& Kéry, M. 2001. Habitat selection of Corncrakes (Crex crex L.) in Szatmár-Bereg (Hungary) and implications for further monitoring. - Ornis Hungarica 11: 9-18.

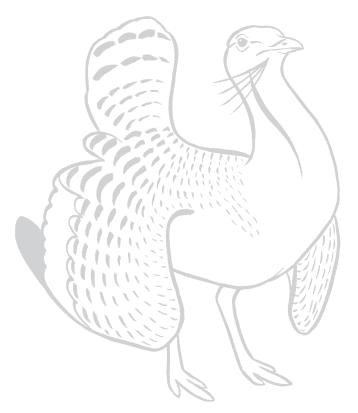

